\title{
PLANNING DECISIONS IN LANDSLIDE AREAS
}

\author{
Maria Hełdak $^{1 *}$, Jakub Szczepański ${ }^{1}$, Monika Płuciennik $^{1}$, Agnieszka Stacherzak ${ }^{1}$ \\ 1 Wroclaw University of Environmental and Life Sciences, C.K. Norwida 25 Str., 50-375 Wrocław, Poland \\ * Department of Spatial Economy, e-mail: maria.heldak@up.wroc.pl
}

Received: 2016.04.26

Accepted: 2016.08.07

Published: 2016.09 .20

\begin{abstract}
The study discusses the topic of planning decisions taken for the purposes of studies prepared on the municipality level and related to the development of landslide areas in Poland. The aim of the research is to demonstrate the scale of the issue consisting in designating areas at risk of subsidence of soil masses for investment purposes. The research emphasises the essential role of planning documentation in the prevention of investment in such areas. Other vital factors also include the SOPO (Landslide Counteracting System) database as well as the staroste, who, in the course of preparation of planning documentation and issuing decisions on development conditions, issues opinions or agrees (depending on the type of document or decision) on the planned investment in areas at risk of landslides. The study shows the complexity of the spatial planning and development system in Poland and the significant influence of bodies and institutions on the planned development of areas prone to the subsidence of soil masses.
\end{abstract}

Keywords: landslide, spatial planning, environmental protection authority, geological protection

\section{INTRODUCTION}

Spatial policy on the local level in Poland and its implementation based on local spatial development plans currently uses quite inefficient tools to verify the aspirations of local authorities. Such bodies often designate new land for investment purposes without taking into account the consequences resulting from threats to human life and health.

At the same time, the free space left around us is constantly shrinking, as it is taken over by the settlement function, which often expands into areas at risk of landslides. The question is how to make both local authorities and the inhabitants of the given municipality aware of the threats caused by the unrestrained desire to develop land? [Hełdak and Raszka, 2013].

One of the elements which should be included in the spatial policy of a municipality is a thorough consideration of threats to the safety of the inhabitants and their property, as well as the iden- tification of areas of natural geological hazards. Therefore, the study of conditions and directions of spatial management includes, among others, areas of particular risk related to the subsidence of soil masses, i.e. landslide areas. The local land use plan, related to the study of the municipality, should also define the boundaries and development methods of land or structures subject to protection, including areas at particular risk to landslides [Bydłosz and Hanusz, 2013].

The number of mass movements in Polish Carpathians amounts to approximately 35000 , which accounts for over $90 \%$ of all occurrences in the country. Every year they cause huge economic losses. It was especially noticeable during the flood in May-June 2010. Its activation caused damage to infrastructure, danger to humans and economic difficulties. In the Polish Carpathians one landslide is reported per each square kilometre of area and per every five kilometres of public road [Hutchinson, 1988; Cruden and Varnes, 1996; Bednarczyk, 2014]. 
In 2005, according to preliminary estimations, the number of landslides and areas at risk of landslides in the Carpathians exceeded 20,000. Works conducted within the SOPO (Landslide Counteracting System) Project allowed for the extrapolation of data from selected Carpathian municipalities to the remaining areas of the Carpathians. According to current estimations, the number of landslides in the Carpathians may fall into the range between 50 and 60 thousand. The estimated "landslide indicator" that expresses the proportion of the area of land subject or prone to landslides to the total land area reaches $30-40 \%$ in the Carpathians [Ministry of the Environment].

These data motivated us to initiate the research on the use of the Landslide Counteracting System in planning studies created in Poland, in the Tatrzanski poviat located in the Malopolskie Voivodeship.

The aim of the research is to demonstrate the scale of the issue consisting in designating areas threatened by subsidence of soil masses for investment purposes. The research emphasises the essential role of planning documentation in the protection of such areas from being developed. Other factors that play a vital role include the SOPO (Landslide Counteracting System) database as well as the staroste, who, in the course of preparation of planning documentation and issuing decisions on development conditions, issues opinions or agrees (depending on the type of document or decision) on the planned investment in areas at risk of landslides.

In Poland, this issue has been the subject of scientific analyses for many years. However, the topic of spatial development of areas prone to the subsidence of soil masses is still important and causes a lot of emotions. According to Guzzetti F. [2015], landslides, like other natural hazards, are difficult to predict. The difficulty arises from the poor understanding of the phenomena that control landslides, and from the inherent low predictability of landslides, a result of their complexity and chaotic nature [Turcotte et al., 2002].

Throughout the world, the issue of the influence of development on the occurrence of landslides and the risk connected with the subsidence of soil masses has been discussed by numerous researchers, including Guzzetti F. [2015]. The subject of the influence of changes in land use on the occurrence of landslides was analysed by Reichenbach P. et al. [2014]. According to the authors [Reichenbach et al., 2014], changes in land use distribution and type can be natural or induced and controlled by human actions. Recent studies focusing on the effect of human-induced land use changes on slope stability have shown that in populated regions, the impact of humans on the environment contributes significantly to the initiation and reactivation of landslides [Vanacker et al., 2003; Meusburger and Alewell, 2008; Bruschi et al., 2013].

Literature also discusses methods of determination of areas at risk of potential geological hazards, i.e. areas prone to subsidence of soil masses, considering the changes in land use. Landslide susceptibility (LS) was described by Brabb [1984] as the likelihood of a landslide occurring in an area on the basis of local terrain conditions, and it can be defined as the extent to which an area can be affected by future slope movements [Guzzetti et al., 1999, 2005, 2006].

To do so, historical and contemporary maps should be compared with the development of land [Reichenbach et al., 2014]. The resulting maps are created with use of various multi-dimensional statistical classification techniques.

To analyse the effect of land use change, the authors have applied the derived models in the same area considering the land use distribution obtained from a single aerial photograph taken in 1954.

\section{MATERIAL AND METHODS}

The study discusses the issue of designating landslide areas and areas prone to the subsidence of soil masses for investment purposes. The Tatrzanski poviat, municipalities Kościelisko and Bukowina Tatrzańska in the Malopolskie Voivodeship were selected for detailed analysis (Fig. 1). The development of the discussed areas is often a thing of the past, and historical development is often located in areas that are currently classified as prone to the subsidence of soil masses.

The scope of research includes:

- the disclosure of landslides and areas at risk of subsidence of soil masses in the spatial policy of the Bukowina Tatrzańska and Kościelisko municipalities and the specification of sources of data about areas prone to landslides.

- the disclosure of the scale of designating landslide areas for purposes other than agriculture or forestry in binding local spatial development plans for the municipalities in question. 


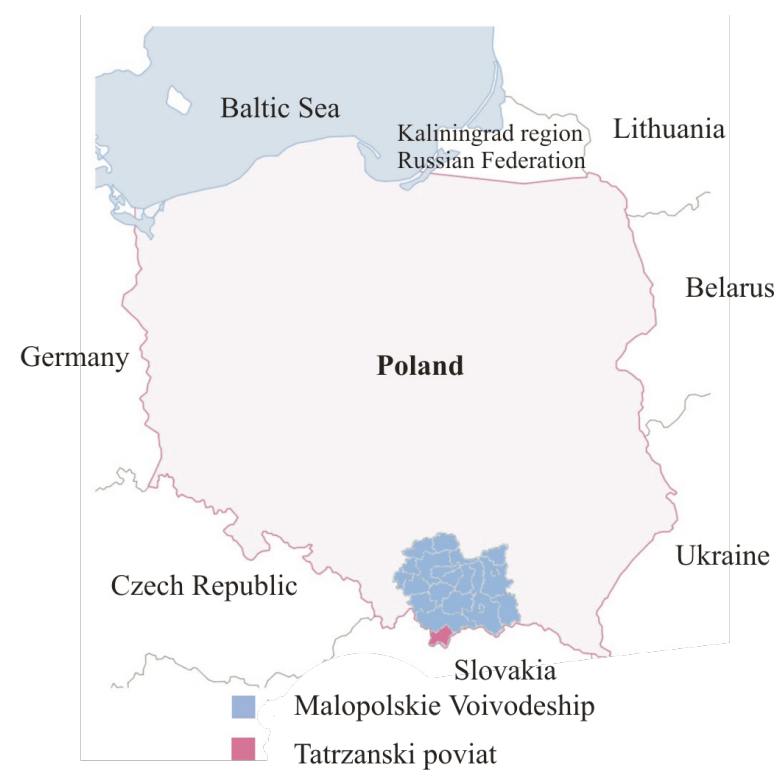

Figure 1. Location against Polish and voivodeships.

- pointing out the attempts to include regulations aimed at the reinforcement of investment principles in areas prone to the subsidence of soil masses in local spatial development plans.

The study involved an analysis of the degree of inclusion of the identified landslide areas and areas at risk of the subsidence of soil masses, within the SOPO (Landslide Counteracting System) in planning documentation. The analysed documents include the study of conditions and directions of land development of the given municipality, as well as local spatial development plans. This article identifies the function of areas at risk as specified in the planning documents and the problems connected with the preparation of such documentation.

The authors used source materials based on their own observations (direct observations), which are characterised by high reliability of data and the possibility to verify it on an ongoing basis as well as the information collected by National Geological Services within the SOPO (Landslide Counteracting System). Information constituting source materials and the basis for the conducted analyses are not gathered by the information departments of national statistical services or other entities operating in the field of real estate. The inventory of the area of the Kościelisko municipality with respect to geological hazards within the SOPO system was taken by Dariusz Wieczorek and Andrzej Stroiński [2010].

The collected data was analysed with use of comparative analysis. This is one of the most commonly applied methods. The specifications of planning documents pertaining to the identification of landslide areas and areas at risk of subsidence of soil masses were compared, including the identification of these types of areas and their designation in spatial policy and local planning. The aim of the analysis is to determine certain relations, such as identity, similarity or difference between properties and facts. This method is used for the determination and assessment of basic causative relations that occur in the analysed objects.

\section{GEOLOGICAL STRUCTURE}

The Tatra and the Podhale region are part of the Alpine soil-formation system. The geological structure of the Bukowina Tatrzańska municipality involves three elements: granite from the Tatra, Mesozoic sedimentary rocks and flysch. The first two elements belong to the Tatra, while the third one can be found in Podhale. The region where granites are present ranges from the state border in the South to the latitude of the mouth of the Waksmund valley. Mesozoic sedimentary rocks of the Triassic, Jurassic and Cretaceous period reach as far as the Wierch Poroniec Peak. In Międzydrogi and Wierch Poroniec Peak they are covered by a thick deposit of conglomerate and sandstone. In the northern part of the municipality, where all the villages are located, the soil consists of Podhale flysch, i.e. interchanging layers of sandstone and slate from the Tertiary period. The Tatra valleys are covered with a thick layer of Quaternary scree, from under which granite rocks and Mesozoic sedimentary rocks are revealed only on ridges.

What is characteristic, due to the geological structure (high amount of slate) and steep slopes, are landslides, or, rather, areas susceptible to the occurrence of landslides. Although they are currently quite stabilised, any disturbance of the static balance of the slopes may activate them.

A situation in which often highly permeable rigid rocks tectonically overlie weak (plastic, impermeable) formations is suitable both for the evolution of deep-seated failures (e.g. lateral spreading) in upper parts of slopes and for the activation of shallow landslides and earthflows in often undrained conditions at the base of the slopes. In some examples, rigid bedrock sinks to underlying weak formations and creates bulging and valley-anticlines as it was identified in many 
geodynamical settings [Panek et. al. 2009; Záruba, Mencl, 1987; Martino et al., 2004].

The division into geological regions discussed above is reflected in the height structure. The highest part consists of granites, while the medium section are Mesozoic sediment rocks and the lowest - Podhale flysch [Bober, 1984].

The whole area of the Kościelisko municipality is located within two tectonic units of the internal Carpathians: the Tatra and Podhale [Piotrowska et al., 2008a, 2008b]. The area of the Kościelisko municipality (with the exception of the Tatra National Park) contains only post-tectogenic cover of Podhale flysch and Quaternary sediments. The flysch that is present in the discussed area contains the Zakopane layers (upper and lower), Chocholow layers (upper and lower) and ostryskie layers.

The sediments of Podhale flysch consist nearly only of interbedded sandstone and slate.

\section{LANDSLIDE COUNTERACTING SYSTEM (SOPO)}

The Landslide Counteracting System is a system of national importance, whose main objective is to identify, document and mark on a map in the scale of 1: 10,000 all landslides and areas potentially susceptible to the subsidence of soil masses in Poland. Additionally, the aim of the system is to enable the implementation of an indepth and superficial monitoring system on 100 selected landslides. The overall objective of the project is to support local authorities in the performance of their duties with respect to the issues of soil mass movements pursuant to the relevant statutes and regulations.

Automatic on-line systems are expensive, but more useful in high-risk areas [Senneset, 1998; Agnelli et al., 2000; Aylsworth et al., 2000]. They allow for a quick and easy access to landslide data in real time and warn about hazards. In conjunction with numerical modelling, they enable the possibility of stabilization and control to be determined [Bednarczyk, 2014].

The aim of this venture is to support the starostes in the efficient performance of their duties imposed by the Regulation of the Minister of Environment of June 20, 2007 concerning information on land mass movements [Journal of Laws No. 121, item 840], i.e. to provide them with complete and accurate data for efficient landslide risk management.
Geological research of landslides has been included in the activities of the Ministry of Environment within the scope of its competences mainly in order to provide substantial and financial support to municipalities and poviats in the fulfilment of their tasks specified in legal regulations with respect to landslides, counteracting their occurrence and removal of consequences as well as spatial planning in landslide areas. The realisation of this task will enable geological administration on poviat level to become actively involved in the process of spatial planning and issuing location decisions in such areas.

The task consisting in taking inventory of landslide areas and areas prone to subsidence of soil masses has been divided into three stages:

1. Stage I (2006-2008) - Initial mapping of landslides with the identification of areas where they occur in Poland;

2. Stage II (2008-2014) - Mapping and creating maps of landslide areas and areas at risk of subsidence of soil masses for the Polish Carpathians $(75 \%$ of the surface area) and monitoring selected landslides in the Carpathians;

3. Stage III (planned for the years 2015-2018) Mapping and creating maps of landslide areas and areas at risk of subsidence of soil masses for the Polish Carpathians (25\% of the surface area) and the remaining areas of Poland and monitoring selected landslides in the Carpathians and in other areas.

\section{INCLUDING LANDSLIDE AREAS IN THE SPATIAL POLICY OF MUNICIPALITIES}

One of the vital elements of the spatial planning process is obtaining the results of geological surveys by local territorial self-government administration, in order to enable attempts to successfully prevent landslides and to remove their consequences.

In the Polish spatial planning system, as far as defining the function and development conditions of land is concerned, municipalities are currently much more independent that they used to be before the political transformation [Leoński and Szewczyk, 1999; Hełdak, 2012]. The currently binding Act of July 112003 on Spatial Planning and Land Development (Journal of Laws of 2015, item 199, including further amendments) maintained these legal conditions. However, the freedom of a municipality to determine the func- 
tion of land is limited by the competences of the voivode, voivodeship and poviat management authorities with respect to the relevant government and self-government tasks, as well as by the competences of other bodies and institutions authorised to issue opinions and to agree on the spatial development directions and conditions study and drafts of local spatial development plans. Moreover, the voivode acts as a supervisory authority with respect to the resolutions concerning the study and local plans [Hełdak, 2012]. The spatial development directions and conditions study prepared on the municipality level has the nature of an internal administration act. This means that it is binding for the bodies and organisational units of the municipality that are directly involved in the spatial planning process in the area of the given municipality, including those that prepare a draft of the local plan [Kwaśniak, 2011].

One of the authorities responsible for issuing opinions on drafts of spatial development directions and conditions studies and, at the same time, for approving spatial development plans in the given poviat with respect to geological hazards is the staroste.

The main problems of future spatial development should be solved on the stage of formulating spatial policy. Moreover, the provisions of the study are binding for the municipality in the process of creating the local spatial development plan, thus, the provisions contained in this document are vital for spatial planning. Spatial policy should counteract excessive investment plans, to protect free, biologically active (unsealed) space.

The subject matter of the study document includes a wide range of issues (pursuant to Art. 10 of the Spatial Planning and Land Development Act) that allows for a detailed analysis of the existing, current development state of the municipality, including the identification of valuable elements of the natural and cultural environment as well as threats for spatial development. The study takes into account the conditions connected with the functioning of the natural environment, including, among others, the presence of natural geological hazard areas.

The development directions specified in the study document include the determination of changes in the spatial structure of the municipality, including, among others, in agricultural and forest areas the directions and indicators related to land development and usage, including land excluded from development, areas and principles of the protection of environment and its resources, environmental protection as well as areas particularly susceptible to floods and landslide areas.

This means that landslide areas have to be taken into account in further development directions for the municipality.

The analysed municipalities have binding spatial policy documentation (Spatial development directions and conditions studies) that were updated in various years and to a various extent, either in form of a new study or modifications concerning the whole municipality or only a part of it.

These documents present different approaches to the issues of landslides and areas prone to the subsidence of soil masses. The binding study... for the Kościelisko municipality does not take landslide areas into consideration in the original document defining spatial planning. Recently, after the inventory, within the Landslide Counteracting System (SOPO), the modification of the provisions of the text and drawings of the document has been initiated. Works on the modification and supplementation of spatial policy in the Kościelisko municipality are still in progress (Fig. 2A-D).

The SOPO system belongs to the main sources of information about landslides used in the spatial planning process. The currently prepared draft of the spatial development directions and conditions study of the Kościelisko municipality takes into account areas at risk of subsidence of soil masses. However, the problem is the lack of information about the risk of landslides for the area of the Tatra National Park.

Additionally, the original spatial policy of the Kościelisko municipality did not take into consideration the areas prone to subsidence of soil masses, which led to the fact that a large area of this type of land was designated for investment purposes. The scale of the problem increases as the spatial policy constituted a basis for the preparation of local spatial development plans that are the final stage of the planning process before issuing a building permit.

The Tatrzanski Poviat is not wholly covered with the Landslide Counteracting System yet, thus, not all municipalities may use the information contained therein for the preparation of planning documentation. In the Bukowina Tatrzańska municipality, some of the areas were recorded in inventory in the aspect of geological hazards in the additional geological and engineering documentation created in the course of the works on 


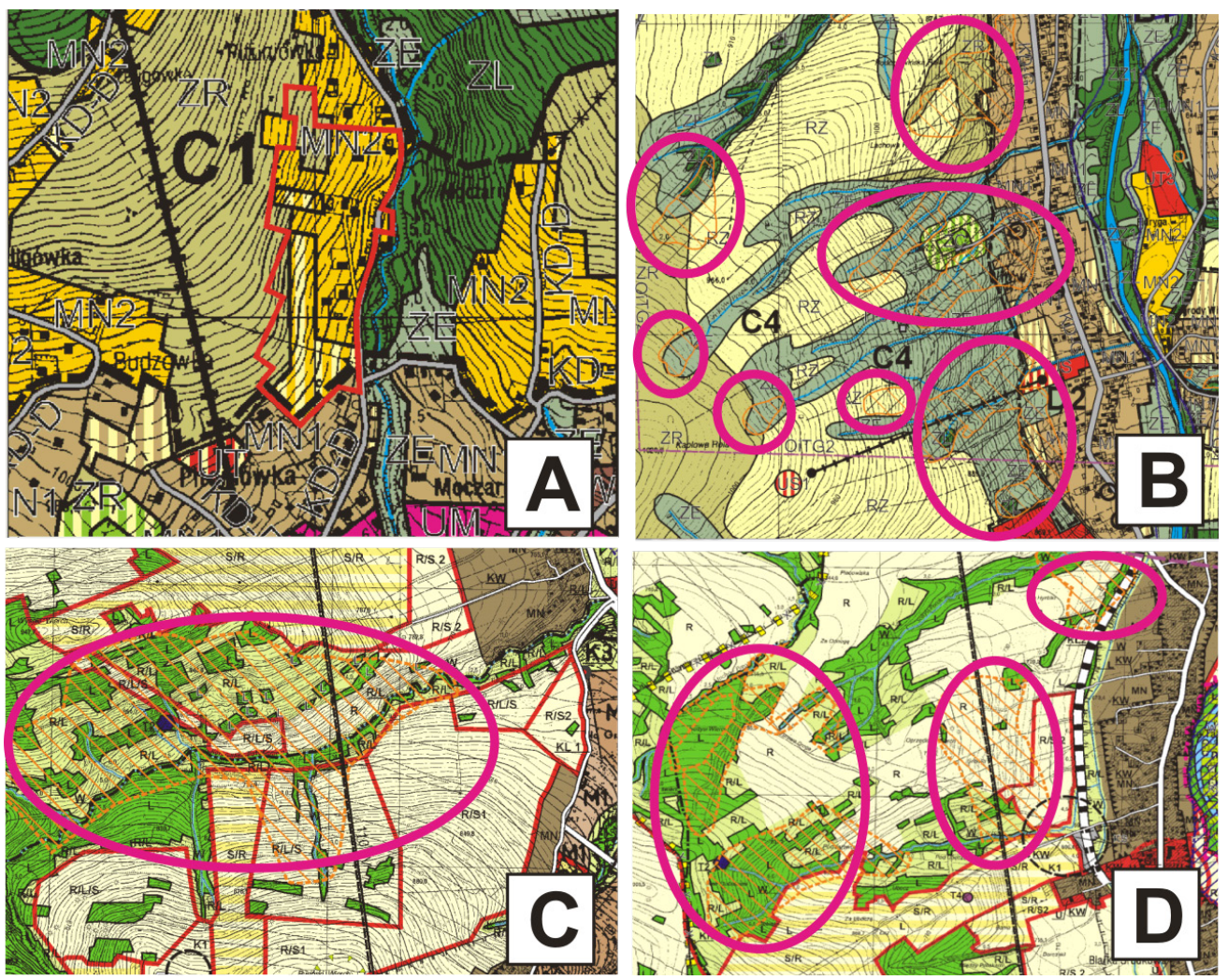

Figure 2. A-D. Spatial policy of the municipalities Kościelisko and Bukowina Tatrzańska; A. Fragment of the spatial development directions and conditions study without identified areas at risk of the subsidence of soil masses in the Kościelisko municipality; B. Fragment of a document (still in progress) with marked areas at risk of subsidence of soil masses in Kościelisko municipality - risk areas were marked basing on the Landslide Counteracting System (SOPO); C. Fragment of the document with identified areas at risk of subsidence of soil masses, pursuant to engineering and geological documentation in the Bukowina Tatrzańska municipality, village Bukowina Tatrzańska; D. Fragment of the document with identified areas at risk of subsidence of soil masses, pursuant to engineering and geological documentation in the Bukowina Tatrzańska municipality, village Białka Tatrzańska;

the modification of the study. The municipality still does not have a Landslide Counteracting System (SOPO), but areas prone to geological hazards have been identified in the documentation and taken into account in the spatial policy.

\section{FUNCTIONS OF LAND IN AREAS AT RISK OF SUBSIDENCE OF SOIL MASSES}

The realisation of investments pursuant to a local spatial development plan remains the desirable way of spatial development in Poland. Such plan is a tool for the realisation of the spatial policy outlined in the study of conditions and directions of land development of the given municipality. According to Kwaśniak [2011], spatial planning is a continuous process that should be based on a certain developmental concept in the spatial aspect. Without a properly formulated development concept in the phase of spatial policy, spatial development enters a dangerous ground, where the consequences may destroy the natural equilibrium.

The tool for the realisation of the spatial policy adopted in the study of conditions and directions of land development of the given municipality, as well as for the regulation of the way of exercising ownership rights in Poland is the local spatial development plan. The preparation of such spatial development plan by a municipality leads to a series of consequences, not only financial, but also of a social, environmental and spatial nature.

The local spatial development plan includes, among others, the borders and ways of development of areas or objects subject to protection determined pursuant to separate regulations, including mining areas and areas particularly threatened by floods as well as landslide areas.

Tests have demonstrated that in landslide areas functions were planned, whose realisation is conflicting with the geological and engineer- 
ing conditions of the soil, which may result in a construction disaster or in a threat to human life and health.

As it was determined basing on the Map of landslides and areas at risk of mass soil movements [Wieczorek and Stroiński, 2010], the total landslide areas in the Kościelisko municipality occupy 317.95 ha, of which the largest geological hazard area exists in Witow (264.35 ha), followed by Dzianisz (25.10 ha) and in Kościelisko (12.88 ha). In Witow, the largest landslide of a complex-variable type occupies an area of 169 ha, and flow-type landslides are present throughout the village, with 41 identified locations occupying a total surface area of 93.27 ha.

In local spatial development plans adopted in the Kościelisko municipality before 2010 , landslide hazards were not taken into account, although such risk existed. This was caused by the lack of identification of such threats in the spatial policy of the municipality (the spatial development directions and conditions study), which resulted in the lack of identification and consideration in local planning. On the other hand, local plans created after 2010 (after the implementation of the Landslide Counteracting System (SOPO) for the Kościelisko municipality), landslide areas and areas at risk of subsidence of soil masses are taken into account in the designation of land functions. Such areas are listed only in 3 binding local spatial development plans in the Kościelisko municipality. The development of the fourth plan has been postponed.

In the Bukowina Tatrzańska municipality, landslide areas are recorded in all created spatial development plans as a result of taking into account the spatial policy of the municipality. However, due to non-compliance with legal regulations, the provisions adopted with respect to landslides in the villages Czarna Góra and Jurgów were repealed by the Resolution of the competent Voivode. However, such situation is extremely dangerous, considering the actual geological hazards in both these villages. The landslide areas in Bukowina Tatrzańska municipality are currently recorded in two binding spatial development plans.

The types of functions and their areas as specified in local spatial development plans in landslide areas and areas at risk of the subsidence of soil for the municipalities Kościelisko and Bukowina Tatrzańska are listed below (Table 1).

Table 1. Land functions specified in local spatial development plans in areas at risk of the subsidence of soil masses - the municipalities Kościelisko and Bukowina Tatrzańska

\begin{tabular}{|c|c|c|c|c|c|c|c|c|}
\hline \multirow[b]{2}{*}{ No. } & \multirow{2}{*}{$\begin{array}{c}\text { Local spatial } \\
\text { development } \\
\text { plan } \\
\text { MPZP* }^{*}\end{array}$} & \multirow{2}{*}{$\begin{array}{l}\text { Area of } \\
\text { landslide } \\
\text { areas in } \\
\text { plans [ha] }\end{array}$} & \multicolumn{5}{|c|}{ Designation of the areas at risk of subsidence of soil masses: } & \multirow{2}{*}{$\begin{array}{l}\text { Share of } \\
\text { developed } \\
\text { land } \\
\text { [ha] }\end{array}$} \\
\hline & & & $\begin{array}{l}\text { residential } \\
\text { develop- } \\
\text { ment [ha] }\end{array}$ & $\begin{array}{c}\text { farming } \\
\text { develop- } \\
\text { pment [ha] }\end{array}$ & $\begin{array}{c}\text { agricultural land } \\
\text { [ha] }\end{array}$ & $\begin{array}{c}\text { sport } \\
\text { services } \\
\text { areas [ha] }\end{array}$ & $\begin{array}{c}\text { forest area } \\
\text { [ha] }\end{array}$ & \\
\hline 1. & $\begin{array}{r}\text { MPZP* } \\
\text { Pitoniówka, } \\
\text { gmina } \\
\text { Kościelisko }\end{array}$ & 4.8425 & & 3.8025 & 1.0400 & & & 1.0400 \\
\hline 2. & $\begin{array}{r}\text { MPZP* } \\
\text { Blachówka, } \\
\text { gmina } \\
\text { Kościelisko }\end{array}$ & 0.4110 & 0.1800 & 0.1710 & 0.0600 & & & 0.0860 \\
\hline 3. & $\begin{array}{r}\text { MPZP Rola } \\
\text { Szatanowa, } \\
\text { gmina } \\
\text { Kościelisko } \\
\end{array}$ & 0.3680 & & & 0.3680 & & & \\
\hline 4. & $\begin{array}{r}\text { MPZP* Lachowa } \\
\text { Rola, gmina } \\
\text { Kościelisko }\end{array}$ & \multicolumn{5}{|c|}{ The development of local spatial development plan was postponed } & & \\
\hline 5. & $\begin{array}{r}\text { MPZP* Wierch }^{*} \text { Rusiński II, } \\
\text { gm. Bukowina } \\
\text { Tatrzańska }\end{array}$ & 8.5500 & & & 3.5500 & 2.5000 & 2.5000 & \\
\hline 6. & $\begin{array}{r}\text { MPZP* Czarna } \\
\text { Góra }\end{array}$ & \multicolumn{6}{|c|}{$\begin{array}{l}\text { The provisions of the plan with respect to landslide areas were repealed by a } \\
\text { Resolution of the competent Voivode. }\end{array}$} & \\
\hline 7. & MPZP* Jurgów & \multicolumn{6}{|c|}{$\begin{array}{l}\text { The provisions of the plan with respect to landslide areas were repealed by a } \\
\text { Resolution of the competent Voivode. }\end{array}$} & \\
\hline
\end{tabular}

*MPZP - local spatial development plan 


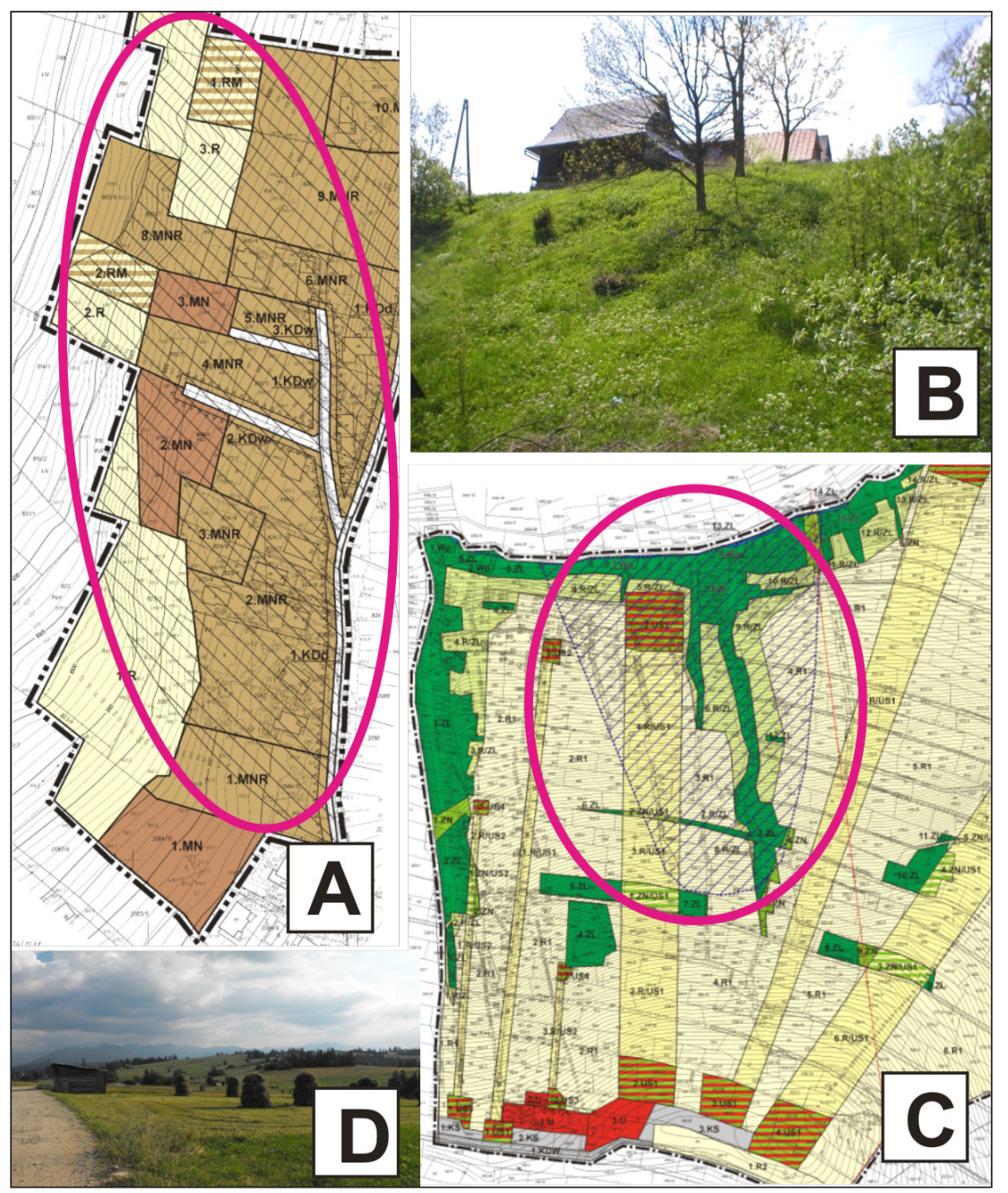

Fig. 3. A-D. Drawings from local spatial development plans with specified investment functions in areas prone to the subsidence of soil masses. A. Local spatial development plan in the Kościelisko municipality, village Pitoniówka; B. View of the land covered by the local spatial development plan in Pitoniówka; C. Local spatial development plan in Bukowina Tatrzańska municipality, Wierch Rusiński. D. View of the land covered by the local spatial development plan.

The list of analysis results demonstrates that in the Kościelisko municipality, various structures are located in landslide areas. These are mostly residential buildings and farmsteads. It was determined that the total number of residential buildings amounted to 16 objects located in areas designated for single-family residential development and farming development (marked by the MNR symbol in drawings in the local spatial development plan). The highest share of geological hazard areas was designated for development purposes in the region of Pitoniówka, village Kościelisko (Fig. 3A-C). Here, the surface area of new residential areas amounts to approx. 2.76 ha. Designating further areas at risk of landslides for investment purposes is believed to pose the greatest threat.
In local plans of the Bukowina Tatrzańska municipality areas prone to the subsidence of soil masses are not designated for residential or farming development (Fig. 3D). However, it was noticed that skiing slopes are being arranged in such areas, which involves the construction of related structures, such as ski lifts or cable cars.

\section{CONCLUSIONS}

The analysis of planning documentation created in the Kościelisko and Bukowina Tatrzańska municipalities has allowed us to formulate the following general conclusions:

1. The lack of identified landslides and areas prone to subsidence of soil masses did not constitute a barrier in the spatial policy of the 
Kościelisko municipality for the creation of local spatial development plans with respect to designating new areas for development.

2. One of the essential features of the Landslide Counteracting System (SOPO) project is the general availability of its results, as all created maps and completed recording charts are gathered in a single database available to all users.

3. The SOPO system enabled to update (complete) the spatial policy with respect to the hazards resulting from the existing landslide areas and areas prone to subsidence of soil masses.

4. Some of the disadvantages of the SOPO system include: too large scale of maps $(1: 10,000)$ in comparison to drawings in local plans (1:1000, 1:2000), lack of identified landslides and areas at risk in the Tatra National Park and the current lack of system for the whole Tatrzanski poviat.

5. What is worth noting is the fact that separate geological and engineering documentation was prepared for the Spatial development directions and conditions study of the Bukowina Tatrzańska municipality, which prevented areas prone to landslides from being designated for development purposes.

\section{REFERENCES}

1. Agneli M.G., Pasuto A., Silvano S. 2000. A critical review of landslide monitoring experiences, Engineering Geology, 55, 133-147.

2. Aylsworth J.M., Duk-Rodkin A., Robertson T., Traynor J.A. 2000. Landslides in the physical environment on Mackenzie Valley, Geological Survey of Canada Bull., No. 547, 41-48.

3. Bednarczyk Z. 2014. Landslide geohazard monitoring, early warning and stabilization control methods. Studia Geotechnica et Mechanica, Vol. XXXVI, No. 1. DOI: 10.2478/sgem-2014-0001.

4. Bober L. 1984. Rejony osuwiskowe w polskich Karpatach fliszowych i ich związek $\mathrm{z}$ budową geologiczną regionu. (Landslide areas in Polish flysch Carpathians and their connection with the geological structure of the region) Biul. Inst. Geol. (Bulletin of the Institute of Geology), 340, 115-162.

5. Brabb E.E. 1984. Innovative approaches to landslide hazard mapping. In: Proceedings 4th international symposium on landslides, Toronto, vol. 1, 307-324.

6. Bruschi V.M., Bonachea J., Remondo J., Go'MezArozamena J., Rivas V., Barbieri M., Capocchi S., Soldati M., Cendrero A. 2013. Land management versus natural factors in land instability: some examples in northern Spain. Environ Manag 52(2), 398-416.

7. Bydłosz J., Hanusz P. 2013. The Impact of Landslide Areas on Municipal Spatial Planning. Real Estate Management and Valuation. Volume 21, Issue 4, Pages 5-10, ISSN (Online) 1733-2478, DOI: 10.2478/remav-2013-0031, January 2014.

8. Cruden D.M., Varnes D.J. 1996. Landslides Types and Processes, [in:] A.K. Turner, R.L. Schuster (eds.), Landslides - Investigation and Mitigation, Washington D.C., National Academy Press, Transportation Research Board Special Report, 247, 36-75.

9. Guzzetti F., Carrara A., Cardinali M., Reichenbach P. 1999. Landslide hazard evaluation: a review of current techniques and their application in a multiscale study, Central Italy. Geomorphology 31, 181-216.

10. Guzzetti F., Reichenbach P., Cardinali M., Galli M., Ardizzone F. 2005. Probabilistic landslide hazard assessment at the basin scale. Geomorphology 72, 272-299

11. Guzzetti F., Reichenbach P., Ardizzone F., Cardinali M., Galli M. 2006. Estimating the quality of landslide susceptibility models. Geomorphology 81:166-184

12. Guzzetti F. 2015. Forecasting natural hazards, performance of scientists, ethics, and the need for transparency. Toxicological \& Environmental Chemistry, http://dx.doi.org/10.1080/02772248.20 15.1030664.

13. Hełdak M., Raszka B. 2011. Prognosis of the Natural Environment Transformations Resulting from Spatial Planning Solutions. Polish Journal of Environmental Studies. Vol. 20, No. 6, 2011, 1513-1518.

14. Hełdak M. 2012. Wpływ decyzji planistycznych na zmiany krajobrazu kulturowego obszarów wiejskich (Impact of planning decision on cultural landscape changes of rural areas). Monografie CL. Uniwersytet Przyrodniczy we Wrocławiu, pp. 201.

15. Hełdak M., Raszka B. 2013. Evaluation of the Spatial Policy of a Commune with Regard to Planned Land Use, Polish Journal of Environmental Studies, 22(1), 125-130.

16. Hutchinson J.N. 1988. General Report Morphological and geotechnical parameters of landslides in relation to geology and hydrogeology, Proceedings Fifth International Symposium on Landslides (ED; Bonnard C.) Balkema, Rotterdam, 3-35.

17. Kwaśniak P. 2011. Plan miejscowy w systemie zagospodarowania przestrzennego (The local spatial development plan as part of the spatial development system). Lexis Nexis, $3^{\text {rd }}$ edition. Warsaw, pp. 335. 
18. Leoński Z., Szzewczyk M. 1999. Podstawowe instytucje planowania przestrzennego i prawa budowlanego (Basic institutions of spatial planning and construction law). Wydawnictwo WSB, Poznań, pp. 216.

19. Martino S., Moscatelli M., Scarcascia Mugnoza G. 2004. Quaternary mass movements controlled by a structurally complex setting in the central Apennines (Italy). Engineering Geology, 72(1-2), 33-55.

20. Meusburger K., Alewell C. 2008. Impacts of anthropogenic and environmental factors on the occurrence of shallow landslides in an alpine catchment (Urseren Valley, Switzerland). Nat Hazards Earth Syst Sci 8, 509-520

21. Ministerstwo Środowiska, 2010. (Ministry of the Environment). Działania resortu środowiska w zakresie systemu osłony przeciwosuwiskowej w Polsce (Activities of the Ministry of the Environment with respect to landslide counteracting system in Poland), Warsaw, September 8, 2010.

22. Pánek T., Smolková V., Hradecký J., Šilhán K. 2009. Late Holocene evolution of landslides in the frontal part of the Magura Nappe: Hlavatá Ridge, Moravian-Silesian Beskids (Czech Republic). Moravian Geographical Reports 17(4), 2-11.

23. Piotrowska K., Bac-Moszaszwili M., Gaździcka E., Iwanow A., Marciniec P., Nescieruk P., Wasiluk R., Zimnal Z. 2008a. Detailed geological map of the Tatra in scale 1:10,000, chart. Kiry. Centralne Arch. Geol. (central Geological Archive), Państw. Inst. Geol. (National Institute of Geology), Warsaw.

24. Piotrowska K., Bac-Moszaszwili M., Gaździcka E., Iwanow A., Marciniec P., Nescieruk P., Wasiluk R., Zimnal Z. 2008b. Detailed geological map of the Tatra in scale 1:10,000, chart. Witów. Cen- tralne Arch. Geol. (central Geological Archive), Państw. Inst. Geol. (National Institute of Geology), Warsaw.

25. Reichenbach P., Busca C., Mondini A.C., Rossi M. 2014. The Influence of Land Use Change on Landslide Susceptibility Zonation: The Briga Catchment Test Site (Messina, Italy). Environmental Management, doi:10.1007/s00267-0140357-0, http://link.springer.com/article/10.1007/ s00267-014-0357-0.

26. Senneset K. 1998. Natural and Man-Hade Hazards: Landslides, Stability analysis, control, case histories, General Report Norges Teknisk-Naturvitenskapelige Universitet, Bull. 34, Trondheim, 1-14.

27. Turcotte D.L., Malamud B.D., Guzzetti F., Reichenbach P. 2002. "Self-organization, the Cascade Model, and Natural Hazards." Proceedings of the National Academy of Sciences of the United States of America 99 (Suppl 1), 2530-2537.

28. Wieczorek D., Stroiński A. 2010. Map of landslides and areas at risk of mass movements of soil in a scale of 1:10000, municipality Kościelisko, Tatrzański poviat, Małopolskie voivodeship. http// geoportal.pgi.gov.pl/portal/page/portal/SOPO [access: May 12 2015].

29. Vanacker V., Vanderschaeghe M., Govers G., Willems E., Poesen J., Deckers J., De Bievre B. 2003. Linking hydrological, infiniti slope stability and land-use change models through GIS for assessing the impact of deforestation on slope stability in high Andean watersheds. Geomorphology 52, 299-315.

30. Záruba Q., Mencl V. 1987. Landslides and Their Control (Developments in Geotechnical Engineering). Elsevier, Amsterdam, pp. 324. 